\title{
Organising decoupling
}

\begin{abstract}
Viele der gravierenden, Länder übergreifende Umweltprobleme sind zu eng mit Wirtschaftswachstum und Lebensstilen verbunden, als dass sie ohne umfassende Änderung der industriellen Produktionsmuster lösbar wären. Transitionsforschung zeigt Wege zur nötigen Veränderung von Industrie und Gesellschaft um die Lebensgrundlagen einer wachsenden Bevölkerung bei Bewahrung der natürlichen Ressourcen langfristig sicherzustellen.
\end{abstract}

$\mathrm{U}$ Von Anna J. Wieczorek und Pier Vellinga ntil the 1960's, the post war economic growth was considered a great achievement of modern societies. The developments after 1960, accompanied by a thorough environmental investigation, proved that economic growth does not necessarily bring environmental benefits. Although the Kuznets curve claims that economic problems are solved when income levels increase, one had to realise that economic growth does not always go hand in hand with preservation of the global environment. Even contrary, it contributes immensely to the degradation of the life support systems. Comprehensive research on the past trends and future prospects has shown that the aim of decoupling environmental degradation from economic growth has only been realised in the case of some emissions in few developed countries.

\section{Kuznets curves deceit}

When we take a closer look at the Environmental Kuznets Curve we discover that indeed it is true but only for local environmental problems such as air contamination or water pollution in the cities. When we talk about environmental problems on a regional level, such as acidification and water quantity/quality issues at the scale of river catchments, there is less evidence that people successfully address these problems as income levels go up. Similar curves drawn for global environmental problems such as climate change and loss of species and habitats do not resemble Environmental Kuznets Curves at all (see figure 1).

Empirical data illustrate that there is no income related leveling off point when we look at the relation between income and emissions of greenhouse gases (given the predominant use of fossil fuels). Environmental problems at this level are challenging because income levels correlate with

\section{Figure 1: Global Average Income Levels and Environmental Quality}

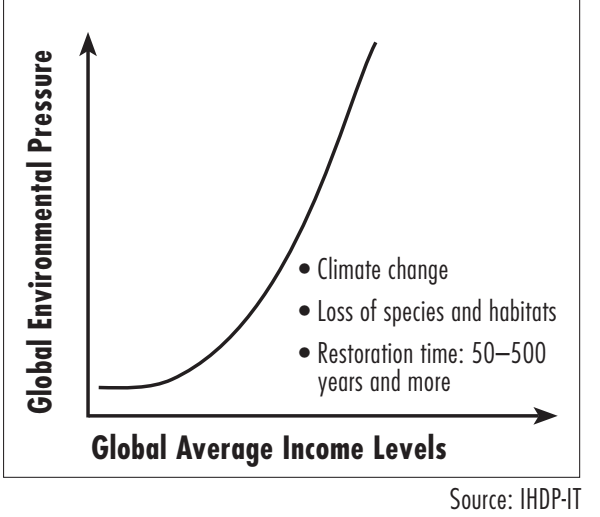

energy use and present day energy use is coupled with carbon dioxide emissions. Similarly, the space and resources we use for our activities like housing, transport, and also recreation grows linearly with income projections going up; this is at the expense of natural habitats.

Even though there has been a great progress made in the field of environmental protection, global environmental change proves to be too complex to be solved with the existing, traditional policies and regulation approaches. This is because the activities causing these problems, energy use, food production, mobility are deeply embedded in our cultures. The global environmental problems often originate from different sources, are characterised by a great number of stakeholders with their interests and are marked by large uncertainties. They are also urgent and require action before the effects actually become visible. Global environmental change will test, in an unprecedented way, the capacity of the human species to manage their activities in a pro-active manner, especially when we want to combine growing income levels with a significant reduction in the impact of human activities on global life support systems.

\section{Adequate research is fundamental}

These considerations and a wide international, multidisciplinary consultation provided foundations for the creation of the Industrial Transformation project (IT) of the International Human Dimensions Programme on Global Environmental Change (IHDP) (1). The IHDP-IT programme is based on the assumption that important changes in production and consumption systems will be required in order to meet the needs and aspirations of a growing world population while using environmental resources in a sustainable manner. This type of research has to be of a multi-disciplinary character.

Since launching of the IT Science Plan in early 2000, a number of relevant research initiatives have been developed worldwide. One aim of these activities has been to inform policies and strategies to realize purposive transitions. The review of research carried out since the launching of the IT Science Plan illustrates that transition research is still in its infancy. The studies show that the road towards sustainability through the decoupling of economic development from its environmental burden poses many challenges. The character of the most urgent global environmental problems legitimises the focus on the transformation of production and consumption of energy, transport, food and water and the technical, institutional and societal elements that shape these systems. There is a consensus that effective research approaches should include the analyses of technological, socio-economic and institutional change. Such multidisciplinary approaches are generally presented under the name of industrial transformation research.

\section{Anmerkung}

(1) For more information on IHDP - IT visit www.uni-bonn. de/IHDP and www.vu.nl/ivm/research/ihdp-it

\section{Die Autorlnnen}

Anna Wieczorek leitet die Geschäftsstelle des Industrial Transformation-Projekts International Human Dimensions Programme on Global Environmental Change (IHDP IT). Prof. Pier Vellinga ist Vorstand des IHDP IT Projekts. Kontakt: IHDP IT Project, c/o Institute for Environmental Studies (IVM), De Boelelaan 1087, 1081 HV Amsterdam, Niederlande. E-Mail: anna.j.wieczorek@ivm.vu.nl 
(c) 20I0 Authors; licensee IÖW and oekom verlag. This is an article distributed under the terms of the Creative Commons Attribution Non-Commercial No Derivates License (http://creativecommons.org/licenses/by-nc-nd/3.o/), which permits unrestricted use, distribution, and reproduction in any medium, provided the original work is properly cited. 